\title{
Model of the Hydro-information System in the Republic of Macedonia
}

\author{
Blagoj Delipetrevㄹ, Dragan Mihajlov², \\ Marjan Delipetrev ${ }^{3}$ and Todor Delipetrov ${ }^{3}$ \\ ${ }^{1}$ Faculty of Computer Science and Information Technology, University "Goce Delcev", Stip, Republic of Macedonia \\ ${ }^{2}$ Faculty of Electrical Engineering and Information Technologies, University "Ss Cyril and Methodius", Skopje, \\ Republic of Macedonia \\ ${ }^{3}$ Faculty of Natural and Technical Sciences, University "Goce Delcev", Stip, Republic of Macedonia
}

\begin{abstract}
This paper presents a model of the hydro-information system in the Republic of Macedonia. The model is based on the latest information technologies using GIS, integrated database and specialized applications, allowing further development and upgrade. The paper describes research objectives, methodology of work and expected results in the development of the model of the hydro-information system in the Republic of Macedonia.
\end{abstract}

Keywords: GIS, hydro-information system, information systems, DSS

\section{Introduction}

Issues concerning the management of waters in the world are getting more and more complex. Continuous increase of population, serious problems in providing clean and industrial water and grand investments in the construction of necessary infrastructure motivate the government to seek efficient solutions for successful management of waters. Successful management of waters needs long term planning concerning technical, economic, social and ecological aspects.

Integrated water management needs development of hydro-information system that enables justified distribution of water resources. Hydroinformation system is used for management of limited water resources, evaluation of the risk of floods and droughts, quality of waters, requirements of the population, industry, agriculture, electrical energy etc.

This paper explains the framework for creation of the model of the hydro-information system in the Republic of Macedonia. Model of the hydro-information system is based on GIS technologies, relational database and prototype applications. The paper is a part of my ongoing $\mathrm{PhD}$ research titled "Model of the hydroinformation system in the Republic of Macedonia".

Section 2 gives an overview of the similar project in developed countries and my previous word in GIS, programming, application development, digitalization of maps and other data. Section 3 explains the research objectives and Section 4 the methodology of work. Section 5 describes expected results and benefits from implementation of the project and Section 6 gives conclusions and recommendations.

\section{Motivation and Related Experience}

Water is one of the key priorities in the Millennium Development Goals (MDGs) of the United Nations. Price of clean water is growing and it is an indispensable resource for the future. The Republic of Macedonia is a country divided into two parts concerning water. The western part of the country, due to its geographic position, litological structure and bigger amounts of rain, has more water compared to the eastern part. Climate changes have great impact on the water resources, especially in the eastern part where the amount of water is already insufficient. This issue stimulates research in making a hydro-information system that will allow better water management and utilization. 
Around the world a number of scientists are involved in the field of integrated management of water recourses. The Center for Management of Water Resources in the USA has finished several projects concerning hydro-information systems such as: GIS for Large-scale Watershed Observational Data Model [10], Water management information system for the Rio Bravo/Grande basin: Creation of a geo referenced data base [11], Water availability model and geo-database development for the Rio Grande basin [12] and others.

Research is focused on the development of a decision support system (DSS) as an integral part of hydro-information system. A great number of projects in the field of decision and optimization are the foundation for designing and deploying original solution. Projects like MULINO for creation of a system for integrated water management built on standards of EU - WFD (Water Framework Directive) [9] are a valuable resource. Application MULINO supports design and implementation of operational DSS based on hydro-modeling, multivariable indicators and a spatial multi-criteria procedure for evaluation of management of water resources. PhD thesis of Gijsbers, P.J.A [7] explains the development and implementation of DSS. Similar projects are implemented in many other countries like Romania [1], [8], the USA [5], England. There are several software packages for integrated management of water resources. One of them is WEAP (Water Evaluation and Planning System) which is a tool for planning of water resources. WEAP is often used as an additional tool for evaluation of models, data and other software.

A significant project concerning water management in the Republic of Macedonia is "Integrated development of Vardar Basin" [6]. This project was done in 1975 and described the development of the hydro-system of Vardar basin in the next 50 years.

In the past several years my field of research has been GIS, information system, geo-database repository [3] [4], programming, etc. Simultaneously, a team from the Faculty of Natural Sciences and Technology under my guidance worked on digitalization and vectorization of paper maps and data [2]. The goal was to include digital/vector data into the geo-data repository system. The team worked on the vectorizing of the basic geological map of the Republic of Macedonia in scale 1:200000, hydro-geological map of the Republic of Macedonia in scale 1:200000, and other maps and data. The previous work together with the water-related data collected from Macedonian institutions is the foundation for creating the hydro-information system in the Republic of Macedonia.

\section{Research Objectives}

Research objectives in this project are divided in four packages:

1) Creation of the model of hydro-information system in the Republic of Macedonia and creation of prototype software.

2) Testing and optimization of the model and the software.

3) Validation of the model and software applications with the gathered data.

4) Creation of DSS, testing and evaluation.

Model of the hydro-information system will allow creation of an integral system for water management in the Republic of Macedonia. This will enable control, planning and development in the water sector. The model is based on knowledge and experience of world models having in mind specific characteristics of the hydro-system in the Republic of Macedonia. The system will provide decision support in evaluating different solutions for the most efficient use of water resources.

\section{Methodology of Work}

The project implementation is in three phases, Figure 1. First phase name is input and archiving that starts with gathering of all relevant hydro data in the Republic of Macedonia. These include data of river flows (daily, monthly), levels of dams (daily, monthly), rainfalls, underground waters, weirs, dams, requirements of population, industries, agriculture etc. Most of the data is digital, but there is also paper data. Paper data is converted into digital so it can be used in the model. Almost all data have spatial component and GIS software packages ArcGIS, MapInfo and other are used. Quality of the model depends of the accuracy of the input data. Special procedures and quality check are done in order to have precise and accurate input data. The next step is organizing and archiving 
digital data into relational database. Microsoft SQL server 2005 is used as relational database. Microsoft SQL Server has support for spatial data allowing efficient access, organization, administration and distribution of data. This is a process of building hydro-data repository of all relevant information for the model that will make foundation for the further research and development. Implementation of the relational database Oracle is planned in future development of the hydro-information system.

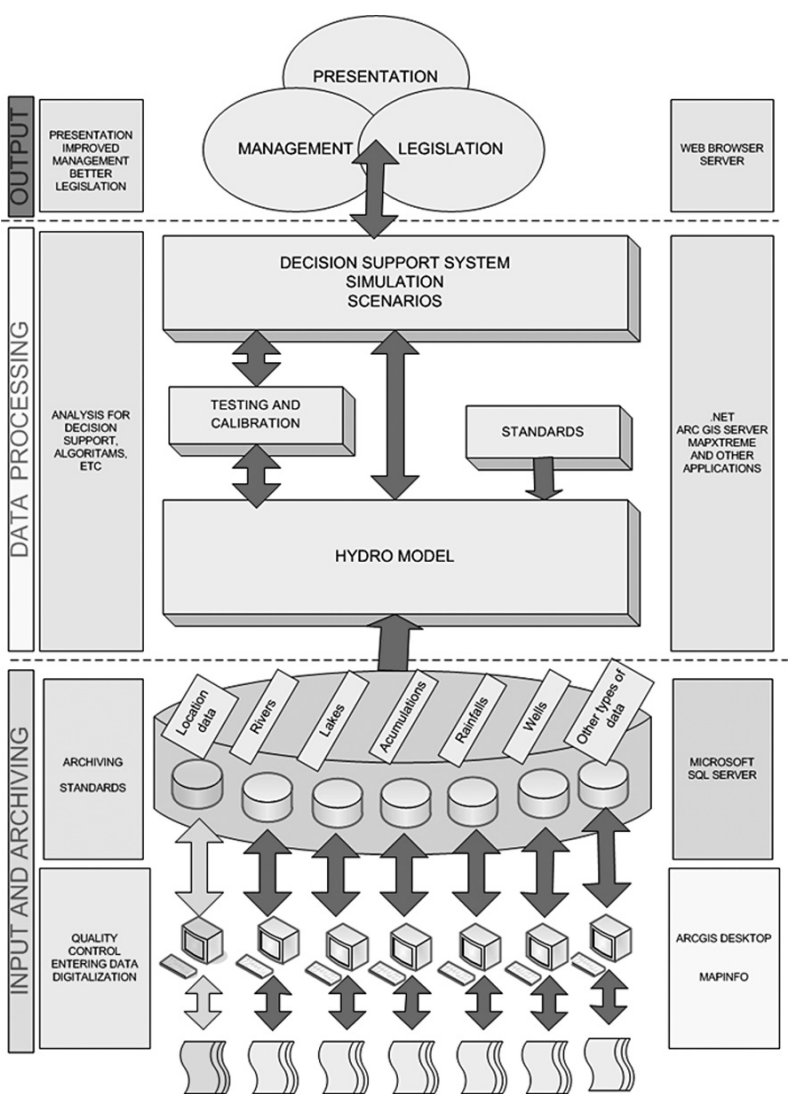

Figure 1. Methodology of work.

Alongside with gathering of the data starts data processing, the second phase of building of the hydro-model in the Republic of Macedonia named data processing. The second phase starts with investigation of similar projects in developed countries and of the existing commercial solutions. This research will provide strategy for the building of the hydro-model. The model will include Macedonian and EU legislative Water Framework Directive (WFD) that will enable achieving EU standards in the Republic of Macedonia concerning water-related issues.

Building of the hydro-model is done using .NET, Java and other platforms and applications com- bined with GIS software packages. Focus will be on building of the application for decision support system (DSS) specialized in water management. Water data have a time parameter that will enable testing, calibration and validation of the hydro model. Next activities are optimization of the model, running simulations and building of the DSS.

The third phase is presentation and dissemination of achieved results to the general public and science community. Presentation of the results will be done on the internet. Implementation of the hydro-information system into state agency for water will provide better management in the water sector and improved legislation based on the results of the model.

\section{Expected Results}

Based on the research objectives and methodology of work, the expected result is the creation of a model of the hydro-information system in the Republic of Macedonia. The hydroinformation system will be based on GIS technologies, relational database and original software applications for optimization, simulation, prediction and decision. The expected results are:

- Creation of centralized GIS system for hydro resources of the Republic of Macedonia including all relevant information for supply/demand of water (rivers, lakes, dams/ towns, industries, agriculture etc.)

- Development of hydro-information system in the Republic of Macedonia based on gathered data.

- Creation of original software application for simulation, prediction and decision regarding management of water resources in the Republic of Macedonia. This will provide solution for optimal use of water potential and future development of the hydro system.

- Comparing the hydro-information system with similar ones from developed countries.

- Possibility to implement this solution in governmental institutions. 


\section{Conclusion}

This paper presents a general overview of the model of the hydro-information system in the Republic of Macedonia. The presented model is based on experiences from the developed countries, taking into consideration the specific characteristics of the Macedonian water information and data. The model is based on the latest information technologies using GIS, integrated database and specialized applications, allowing further development and upgrade. The paper describes research objectives, methodology of work and expected results in the development of the model of the hydro-information system in the Republic of Macedonia. For the completion and implementation of the hydro-information system, government support is required.

\section{References}

[1] M. Adler, G. D. Anderson, D. MCKinney, Decision Support System for Integrated Water Management in Romania: Recent Developments and Future Plans. Proceedings of the conference Integrated water management of transboundary catchments: A contribution from Transcat, Venice, Italy, 24-26 March, 2006.

[2] B. Delipetrov, S. Panovska, M. Delipetrov, G. DIMOV, Digital model of the Basic Geological Map of the Republic of Macedonia. Geologica Makedonica, Vol. 19, 2005.

[3] B. Delipetrov, D. Mihajlov, M. Delipetrov, Geo-database model of the Republic of Macedonia. Proceedings from the 30th International Conference - Information Technology Interfaces, Cavtat/Dubrovnik, Croatia p. 259-262, 23-26 June, 2008 .

[4] B. Delipetrov, D. Mihajlov, T. Delipetrov, Software implementation of the geo-database model of the Republic of Macedonia. Proceedings from the 8th International Scientific Conference SGEM 2008 - Modern mining of mine production, geology and enviromental protection, Volume 2, p. 563-568, Albena, Bulgaria, 16-20 June, 2008.

[5] M. HANNA , Principles of designing and developing spreadsheet-based decision support systems. Master work, University of Florida USA, 2004.

[6] Integrated development of the Vardar basin; UNESCO project, MIT \& Cambrige, 1978.

[7] P. J. A. GiJsBERB, Decision support for the management of the shared water resources: data management as a corestone for joint DSS development, Delft University press, 2000.
[8] M. MATREATA, Overview of the artificial neural networks and fuzzy logic applications in operational hydrological forecasting systems. Proceedings of the conference Balwois, Ohrid, Republic of Macedonia, 23-26 May, 2006.

[9] J. Mysiak, C. GiUPPONI, A. FAssio, Decision Support for Water Resource Management: An Application Example of the MULINO DSS. iEMSs 2002 Integrated Assessment and Decision Support, Proceedings, Vol. 1, 138-143.

[10] C. PATIÑO-GomeZ, D. MCKInNEY, GIS for Largescale Watershed Observational Data Model. CRWR Online Report 05-047, Center for research in water resources, The University of Texas at Austin, USA, December 2005.

[11] C. Patino, D. C. McKinney, D. R. Maidment, Water management information system for the Rio Bravo/Grande basin: Creation of a georeferenced data base. Second International Symposium of Transboundary Waters Management, Tuckon AZ, USA, November 2004.

[12] C. PATINO, D. MCKINNEY, Water availability model and geodatabase development for the Rio Grande basin. First International Symposium on Transboundary Waters Management Monterrey, pp. 155162, Mexico, Nov. 2003.

Received: June, 2009 Accepted: April, 2010

Contact address: M.Sc. Blagoj Delipetrev Faculty of Computer Science and Information Technology University "Goce Delcev" St. Krste Misirkov bb 2000 Stip, Republic of Macedonia e-mail: blagoj.delipetrov@ugd.edu.mk

BlagoJ DeliPETREV received B.Sc. and M.Sc. degrees in Computer Science and Information Technology from the University "Ss Cyril and Methodius" in Skopje. He is currently a PhD student in the department of Hydroinformatics and Knowledge Management at UNESCO-IHE in Delft, the Netherlands. His research interest is in decision support systems, machine learning, GIS and information systems.

DRAGAN MiHAJLOV, full professor, department of Computer Science and Computer Engineering, Faculty of Electrical Engineering and Information Technologies, University Ss. Cyril \& Methodius, Skopje. Areas of interest: programming languages, computer graphics, biocybernetics.

MARJAN DELIPETREV is a research assistant at the Department of Geology and Geophysics, Faculty of Natural and Technical Sciences, University "Goce Delcev" (Stip, Macedonia). His areas of interest include geophysics, geology, geomagnetism and hydrogeology.

TODOR DELIPETROV is a full professor at the Department of Geology and Geophysics, Faculty of Natural and Technical Sciences, Goce Delcev University (Stip, Macedonia). His areas of interest include geophysics, geology, hydrogeology and engineering geology. 